\title{
U.Porto, its Faculty of Engineering and PBL Approaches
}

http://dx.doi.org/10.3991/ijep.v4i1.3261

\author{
Maria Teresa Restivo \\ University of Porto, Porto, Portugal
}

\begin{abstract}
The University of Porto (U.Porto) was founded in 1911. Its Faculty of Engineering (FEUP) is the largest school of U.Porto.
\end{abstract}

U.Porto and FEUP are very active in research, development and innovation with about $20 \%$ of all scientific papers in Portugal among the 15 public Universities in the country.

FEUP is also aware of the important role of higher education in training future engineers. U.Porto and FEUP have been following discussions and significant efforts have been made for promoting teacher professional development in order to guaranty new teaching/learning methodologies and initiatives to promote engineering education.

Diverse initiatives came out since 2000. This work describes different projects specially developed at FEUP like the EMPE project and the FEUP project will be described and results will be addressed. Also, a global and huge program from U.Porto, iJUP, will be presented as very unifying interdisciplinary program at U.Porto involving together teachers/researchers and students from all its 14 schools, and particularly from FEUP.

Index Terms-Engineering students, Professional communication, Project based learning, Qualifications, Research and development.

\section{INTRODUCTION}

The University of Porto (U.Porto) was founded in 1911 and its roots date back to 1762 . At present U.Porto has 3 campuses, 14 Faculties (Architecture, Biomedical Sciences, Dental Medicine, Economics, Engineering, Fine Arts, Humanities, Law, Medicine, Nutrition and Food Sciences, Pharmacy, Psychology and Education Sciences, Science and Sport) and 1 Business School plus $60 \mathrm{R} \& \mathrm{D}$ units. It is a public university with over 31,700 students and around 3000 students are from 106 nationalities. More than 9000 students are at postgraduate level (MSc and $\mathrm{PhD})$. It offers 35 first cycle courses, over 150 integrated or independent masters and 89 third cycle courses. The university has over 1900 teaching \& research (FTE) $(76 \% \mathrm{PhD})$ and around 1700 technical and administrative staff [1]. Its Faculty of Engineering (FEUP), with roots dating back to 1837 , is the largest school at U.Porto, with over 8.700 students, 424 teaching and research staff $(86 \% \mathrm{PhD})$ and 326 non-academic staff [2]. FEUP is under Bologna process since 2006. It has nine Departments: Chemical, Civil, Electrical and Computer, Industrial and Management, Informatics, Mechanical, Metallurgy and Materials, Mining and Physics Engineering. FEUP has been active in the Erasmus mobility program (1988-) and also in Mobile
(2003-), and at present around $8 \%$ of its students are foreign, within 1st and 2 nd cycle degrees and $\mathrm{PhD}$ programs.

U.Porto and FEUP are very active in research, development and innovation: about $20 \%$ of all scientific papers in Portugal are from this centenary university among the 15 public Universities in the country. Naturally, understanding the permanent role of research in the teaching/learning process, U.Porto and FEUP have been aware of world developments in the area of higher education. In 1998 the Boyer Commission Report entitled "Reinventing Undergraduate Education: A Blueprint for America's Research Universities" [3] formulated ten suggestions for improving undergraduate education, the first one being "Make research-based learning the standard". It was stated that traditional lecturing should not be the main instructional approach in a research university, pointing that "The basic idea of learning as inquiry is the same as the idea of research; even though advanced research occurs at advanced levels, undergraduates beginning in the freshman year can learn through research".

Aware of the important role of higher education in training future engineers and so the future decision makers, it is mandatory to disseminate new knowledge in addition to the traditional fundaments and to help students to develop their capabilities in order to guaranty better professional practice and more sustainable societies. U.Porto and FEUP have been following discussions and significant efforts have been made for promoting teacher professional development since the late nineties in order to guaranty new teaching/learning methodologies and initiatives to promote students skills in group work, in cooperation with others, in decision-making processes, in leadership, in interdisciplinary group integration, in intercultural experiences exchange, in society and as responsible for future sustainability [4].

Problem-based learning (PBL) is a model developed at McMaster University in Canada in the late sixties which turned into a successful and innovative method for engineering education [5]. Since then many different types of PBL approaches appeared and U.Porto and FEUP have been following attentively new trends on innovative curricula based in PBL model, as is the case of Problem Based Learning used at Aalborg University (Denmark) since 1974, Project-Based Curriculum at Rowan University (USA) since 1996, and since 2003 greatly improved by its Center for Innovation \& Entrepreneurship, created "combining practitioners and researchers from multiple disciplines in developing entrepreneurial activities" where "Rowan University can build an educational curriculum and a support system that will greatly enhance the ability of students and other key stakeholders to turn ideas into successful growth ventures" [6] or yet the Spiral Curricu- 
lum at Worcester Polytechnic Institute (USA) early experienced in 1997-98 [7].

From this awareness different initiatives came out in FEUP and at U.Porto since 2000. In this work different projects specially developed at FEUP, like the EMPE project and the so called Project FEUP among others, will be described and results will be addressed. Also, a global and huge program from U.Porto, iJUP, will be presented as a very unifying interdisciplinary programme at U.Porto involving together teachers/researchers and students from all its 14 schools.

\section{EMPE -EXPLORATION OF MULTIDISCIPLINARY PROBLEMS IN ENGINEERING}

In the last decades engineering curricula became very specialized and students were exhibiting segmented learning and lack of integration and so more difficulty in getting a comprehensive picture of general fundaments of engineering.

The use of selected multidisciplinary problems attenuates this tendency, helping to integrate knowledge from different fields and to bring opportunity for cooperative teaching/learning/researching, stimulating teachers and students and opening creativity and innovation [8]. Inspired in these beliefs two teachers fostered a pilot multidisciplinary open-ended engineering problem which was deeply exploited. This was based in an everyday and familiar object - a Coca Cola can -[9] and got an extreme success and student involvement (mechanical, civil and communication students) in 2000/2002 at FEUP. Valuable results were obtained showing, as stated in [8], "student teamwork skills and personal responsibility, as well as their self-organizing and conflict-solving capabilities. It develops the students' capacity to analyze, interpret and criticize results, while integrating diverse fundamental concepts in a structured, operational way. And, last but not the least, it most often constitutes a rich learning experience for the teachers involved in such cooperative exercise."

This experience was used by the done FEUP Dean to promote a new project named EMPE -Exploration of Multidisciplinary Problems in Engineering. EMPE was funded by FEUP with a small amount of $19.000 €$ between 2003-2005, and conducted by the two teachers with the main goal of exploring multidisciplinary problems in order to involve all departments and services at FEUP, bringing together teachers, students, technical staff, as well as postgraduate students. EMPE has even promoted collaboration within different schools of U.Porto. A measure of this involvement can be evaluated by its final assets of around 1.000.000€. Such amount had been collected from all colleagues' contribution based in works going on and shared with EMPE activities.

The project started with a team of two responsible teachers, 16 collaborating teachers and 2 students. The initial topics of the project were the following:

- A Coca Cola Can - a small structure - new developments

- Static and dynamic behavior of structures

- Level monitoring and control

- Development of data transfer using internet capabilities

- Wireless sensors
- Development of EMPE webpage for disseminating engineering activities at STEM level and for engineering students.

During this two-year project more than 18 articles involving students were written and more than 12 presentations in conferences were made, 3 e-books were published. Students and teachers were invited speakers for disseminating the project in more than 13 Seminars/Workshop/Conferences. Within EMPE activities 4 MSc theses were finished (2 years pre-Bologna MSc.). Its developed works involved 18 disciplines in regular degrees and 3 in MSc. Therefore, $6 \mathrm{MSc}$ were joining forces with EMPE. The collaborations involved all areas at FEUP and 6 Faculties at U.Porto, the central services at U.Porto and one Associated Laboratory, 8 other public higher education Institutions in Portugal and Budapest University.

This has been an important seed at FEUP for institutional collaborations, socialization of staff and students, opening the door for other initiatives and other project cooperation. EMPE was followed by Experimenta@FEUP for consolidating remote labs at FEUP, in 2006-2008 [10], crossing different areas. Other projects were also supported for increasing the PBL approach.

\section{THE "PROJECT FEUP"}

In May 2004, two years before the Bologna process was implemented at FEUP, the so called "Project FEUP" was approved by FEUP pedagogical board, conceived by Prof. Carlos Costa, the FEUP's Dean between 2001 and 2010. The main goal has been to guide carefully the first steps of every new student arriving at FEUP each year since this could be decisive for his/her future along the graduation process and to help students to understand the impact of engineers in the society, the engineers task in solving problems, and the need for professional ethics and social competences, in line with many others initiatives in the world [11 - 14].

The "Project FEUP" was conceived with the help of a couple of other teachers to be the opening door to a new stage in students life in order to make possible their integration into the FEUP working process also helping the development of students soft skills since the very beginning. This initiative is involving the new comers to nine courses within FEUP - this means around 1000 students/year. This is the biggest discipline at FEUP. Figure 1 shows the distribution by course and numbers related to the academic year 2011/12.

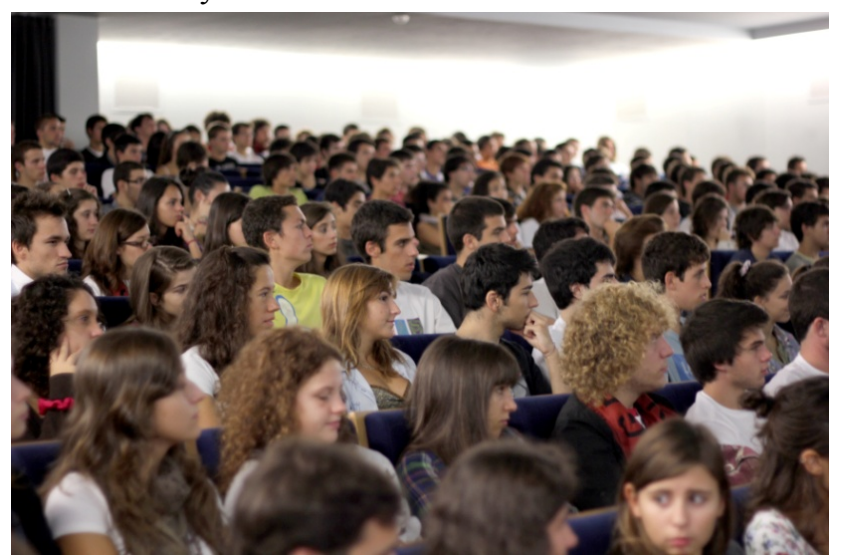

Figure 1. Students in theoretical classes 
PAPER

\section{U.PORTO, ITS FACULTY OF ENGINEERING AND PBL APPROACHES}

Project FEUP is a half semester discipline and has 2 ECTS (European Credit Transfer and Accumulation System) [15] this is, equivalent to 50-60 hours of study (ECTS System "has been adopted in all EU countries for facilitating the transfer and the progression throughout the European Union independently of standard or qualification type used in each country"). The discipline has 92 Professors and Tutors (more than half are teachers). Tutors are students from last years. This is an interesting example of a coaching and a monitoring process. The coaching approach is achieved between the Project FEUP responsible teacher and other collaborating colleagues and the mentoring approach is performed between project FEUP teachers' team and older students, as Tutors.

In the first week theoretical and practical topics are concentrated. Students also have to contact with topics in which each group of 6 elements will be working along the following 4 weeks (supervised by a teacher and a tutor). Then, each group has to make a final presentation in a Congress environment.

During the first lecturing week students have to face subjects as:

- Specific training on professional of non-technical skills:
$\circ$ Writing in engineering
- Effective Communication
○ Visual Communication

Specific topics include ethics, plagiarism, quotation styles, etc.

- Additionally, special initial training is also conveyed on:

\section{○ Campus' Information System \\ ○ Effective Learning}

The course also includes team work about a specific topic within the scope of the program the student was accepted in.

The communication is concentrated in 3 main topics: oral and written communication and visual communication, using posters as a tool. In oral communication students work aspects as voice training, how to write a guide for a subject communication were they also train the "story telling" approach. In the writing aspects the main point is how to make a report: typical structure, references and plagiarism problems. The poster complexity is considered at visual and graphical levels and also at the essential message synthesis. The result of these subjects will come out in the end of the discipline when each team of students will have to produce a scientific report, a poster and an oral presentation according to the proposed "Problem" within a topic related with each student Integrated Master Degree, in the bases of a PBL methodology [16 - 18]. This "Problem" will be followed by the supervising teacher and by a tutor and has to be developed by students during 4 weeks. The report, the poster and the oral communication will be evaluated by teachers and will contribute for the final mark. At the theoretical classes student attendance is controlled by RFID and in the practical classes by registration in Moodle platform.

A sample of some topics related with some of the degrees and respective proposed problems are used just as single example in Table I.
Looking to the survey performed in the academic year 2011-12, it gives us many interesting aspects as students' integration in the workplace and in FEUP structure and culture, their experience in cooperating in new group activities, workload management, etc. Therefore it shows that the initial expectation of students in different dimensions is very high. However, their final satisfaction in the same dimensions is not so high! But, simultaneously, it also shows that the final success rate is very high!

In fact, considering the global number of students enrolled in the discipline 1055, among those 781 from first enrolment phase, only 12 have not been approved at the end of the discipline, this means only $1.5 \%$ ! And, the substantial number of $638(82 \%)$ students got marks higher than 14 (in 20), this means $82 \%$. Combining these two somehow disagreeing results a reason came out and it might be related with the discipline's short duration combined with its low weight (2 ECTS), Figure 2.

The huge number of staff elements involved as well as older students (over 90 people) and student time constraints coming from Bologna process are the main reasons for it being impossible to design FEUP Project as one semester long with a more significant number of ECTS. Following up the effect of this work it also has not such a strong effect as expected in the students' performance in

TABLE I.

SINGLE SAMPLE OF TOPICS AND PROPOSED PROBLEMS

\begin{tabular}{|c|c|c|}
\hline Integrated Master & Topic & Proposed Problem \\
\hline $\begin{array}{l}\text { Environment Engi- } \\
\text { neering }\end{array}$ & $\begin{array}{l}\text { Impact of weather } \\
\text { changes in Portugal }\end{array}$ & $\begin{array}{l}\text { Evaluation based in } \\
\text { measured parameters by } \\
\text { monitoring systems }\end{array}$ \\
\hline Civil Engineering & $\begin{array}{l}\text { Evolution of build- } \\
\text { ing technologies }\end{array}$ & $\begin{array}{l}\text { Which are the most } \\
\text { recent building technol- } \\
\text { ogies? }\end{array}$ \\
\hline $\begin{array}{l}\text { Electronic and Com- } \\
\text { puter Engineering }\end{array}$ & $\begin{array}{l}\text { Distribution of } \\
\text { Electrical Power at } \\
\text { FEUP }\end{array}$ & $\begin{array}{l}\text { System Protection and } \\
\text { suitability for each } \\
\text { output? }\end{array}$ \\
\hline $\begin{array}{l}\text { Mechanical Engineer- } \\
\text { ing }\end{array}$ & $\begin{array}{l}\text { Renewable Energy } \\
\text { and Sustainable } \\
\text { Development }\end{array}$ & $\begin{array}{l}\text { New trends in Energy } \\
\text { production based in } \\
\text { renewable energy } \\
\text { resources }\end{array}$ \\
\hline Chemical Engineering & Production & $\begin{array}{l}\text { Power generation from } \\
\text { biomass }\end{array}$ \\
\hline … & ...... & ....... \\
\hline
\end{tabular}

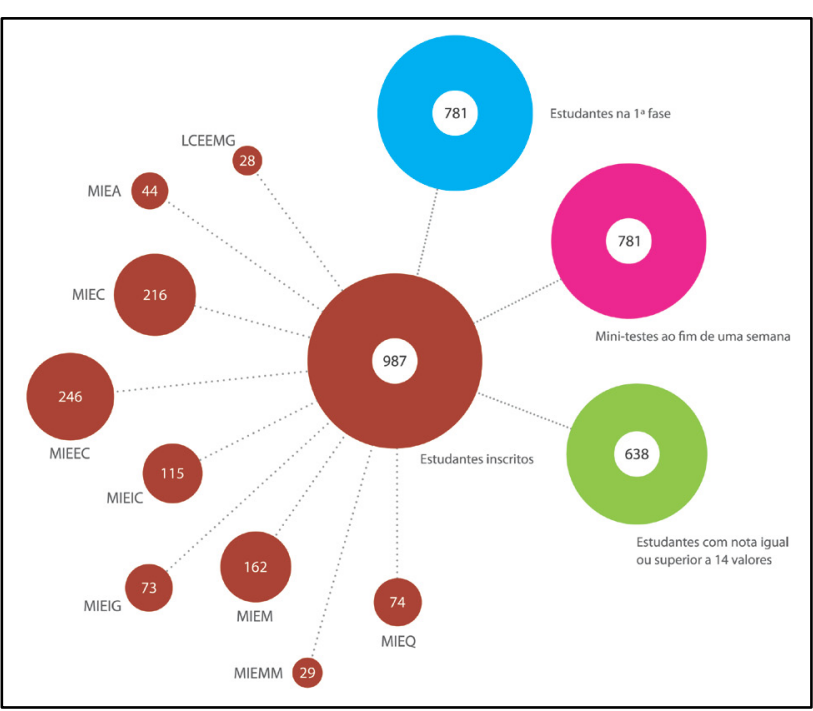

Figure 2. 
PAPER

writing, oral and visual communication skills. And a reason for this is related with the fact that just only in final years students are asked to show these skills. This aspect is also difficult to overcome because this would need the collaboration of all teaching staff at FEUP immediately after this effort of students' initiation in good practices.

\section{IJUP - YOUNG RESEARCH AT U.PORTO}

"The University mission is mainly oriented to the constant advancement of knowledge and innovation, helping human development and also contributing directly to the society in which it is integrated. The actors of this mission are the University academics and students." [19]

"Research based learning should play a paramount role in higher education, all the more so in research universities. In 1998 the Boyer Commission Report entitled Reinventing Undergraduate Education: A Blueprint for America's Research Universities [3] formulated ten suggestions for improving undergraduate education, the first one being Make research-based learning the standard". It was argued that the lecture should not be the primary mode of instruction at a research university. [4]

"Being aware of the importance of undergraduate research, in a pioneering initiative in Portugal U.Porto started in 2004 an annual program entitled Scientific Research at Undergraduate Level aimed at student involvement in research and development activities from freshman level onwards. Based on the perception that only through research can science knowledge be fully and lively understood, the original program and its subsequent evolution (iJUP) are the brainchild of the last two vice-rectors in charge of R\&D policies at U.Porto.’[19]

This program works as a typical research program. It opens with a call for submissions. Any U.Porto Ph.D teacher is free of submitting a proposal based in a structured work like a small project with a defined budget, a team involving some colleagues and students and, if possible, an external institution as industrial labs, enterprises, $\ldots$ and other faculties from U.Porto. The submissions are later evaluated and results are officially published. The project is, itself, the way to remember or convey knowledge, to exercise concepts and bring them to practice, to exercise problem solving capabilities, to be critical and creative, to learn and exercise teamwork competences and to develop communication skills, as well as good experience in convey knowledge, mainly if the team is strongly multidisciplinary. They bring excellent opportunities for practicing the millenary way of building knowledge: learning by doing, thinking and analyzing the result of what was done, correcting problems and redoing solutions in a natural cooperation with teachers. This is a precious process experienced by students leading them to acquire metacognitive skills.

Recently, a former student now working as a R\&D research engineer in an research interface institute at FEUP wrote "These activities during the first years of the author's degree have helped to overcome many of the freshman subjects related with mathematics and conceptual knowledge and turned possible to understand engineering in a much more realistic way than by solving only theoretical problems using paper and pencil." Looking for his experience integrating this type of projects he writes "This experience allowed the author to contact with his teachers in a different base than that in traditional classes, and offered him the capability of discussing solutions and doubts with teachers and colleagues in a team framework. These experiences have been very enthusiastic mainly because he was free to find solutions, often making mistakes and so he got the great opportunity of learning with them. And, in this process the author had a long way to go in finding, guessing, studying, getting the problem key and gathering information about solutions for solving each specific problem. In fact, this was great because the author was normally impressed and shocked by the fact that in traditional engineering teaching students usually have to solve problems and get the correct solution! ... In relation to the students within the team framework the author became able to understand the differences between the team elements... how to work as a team by distributing tasks and how to get how to get the most from each other ... Also, the concept of individual responsibility as a member of the team in charge of one task was perceived. This was also a great opportunity to understand and judge the author's own capabilities and limitations in order to overcome many of them and then widen his knowledge and abilities [20]... The author also had his first opportunity for collaborating in a techno-scientific article [21] submitted to the International iJUP 2009 meeting. In this meeting of more than 700 participants, the author was in contact with Brazilian students and teachers, and also with students and teachers from all the faculties of Porto University and form ERASMUS Mobility programs, by getting in touch with so many distinct projects from all knowledge areas. In fact, it has been important to understand that architecture, humanities, medicine, sports, arts, are areas where engineering needs to be present. This experience contributed again for broadening the author's perspectives flexibility to new ideas and creativity. ... helped the author to understand the different researchers' roles within a team, from those oriented for new technological aspects to the ones engaged with project organization, coordination and overall integration of activities and for the group discussions in major project decisions." [20].

Since 2004 the submissions to iJUP Program have increased consistently according to figure 3 . Figure 4 shows results of such projects presented since the iJUP beginning in 2008.

Program iJUP has another component - iJUP Meeting where students are introduced to an International Conference experience. Every February, a 3-day event brings together Portuguese and international mobility students in this program as well as invited foreign institutions. During these days students present communications and posters in English, previously written and submitted as in a regular conference where they have to answer to audience questions. Proceedings from the last 4 editions have been published by Elsevier and are available at http://ijup.up.pt. Figure 4 illustrates the evolution of communications at iJUP Meetings since 2008. In 2012 the contributions reached the number of 498 and in the present iJUP 2013, there was 463 with 966 registrations. During iJUP Meetings, selected topics are presented by senior teachers or by young successful researchers. A short view from the event prepared for this work is available at http://tv.up.pt/videos/D1aL9Hbz. This Program has received along the years since 2004 financial support from Foundations, Banks and Enterprises. 


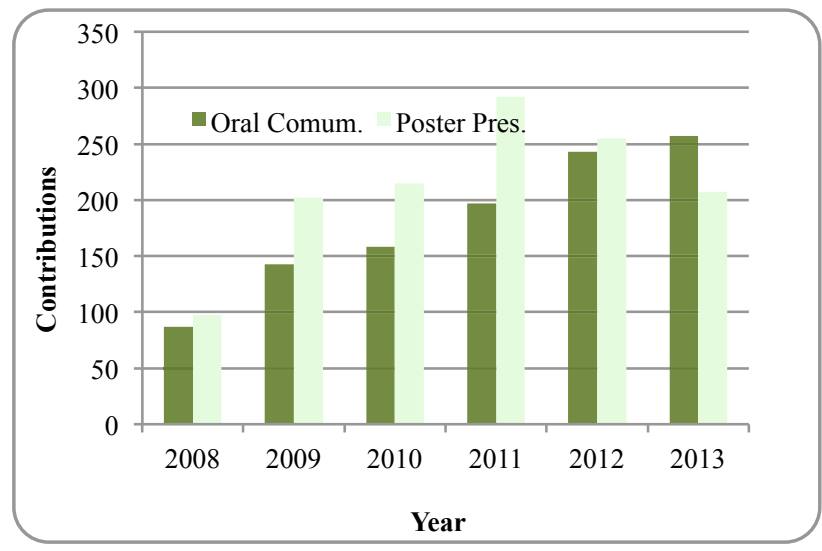

Figure 3. Projects submissions to and approvals

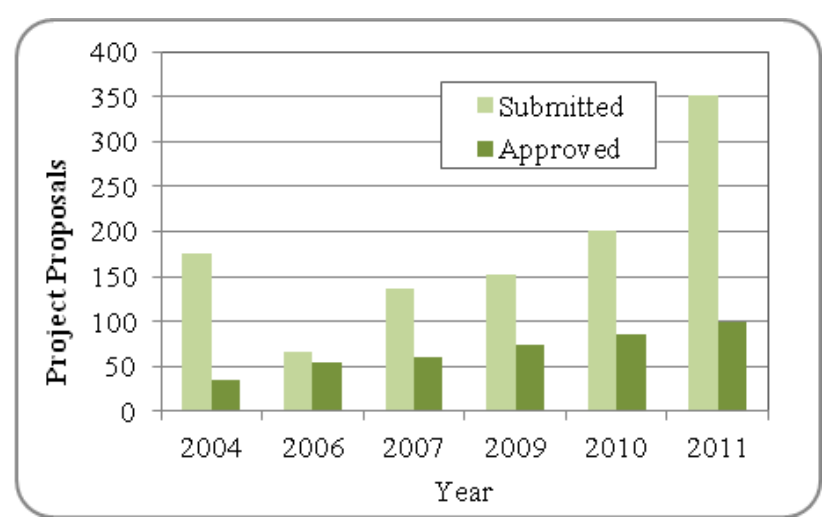

Figure 4. Presentations @ iJUP editions

The author has been involved either as leader or as team element in different projects since its very beginning in 2004. Table II lists the author related projects.

Table III shows for each project the involvements: academics (R), Students (S) and Technicians (T). It is possible to identify teams' multidisciplinarity. With budgets below $5.000 €$ (usually around $3000 €$ ), it is clear that nothing would have been achieved without the enthusiastic, committed and generous participation of many colleagues, students and technicians from several Faculties, Departments, Services, Laboratories, Institutes and Research Centers.

Outcomes of these already finished 10 small projects resulted in 9 prototypes, 5 software applications, 2 awards. Later developments undertaken by researchers added 2 national patents and another 2 (at national and international level) are pending. One of the prototypes is spread in different research groups and, presently, a protocol between U.Porto and an enterprise, is permitting its market evaluation. Ten articles were written in collaboration with students. Collaborations were germinated meanwhile and all these involvements were seeds for other projects between research groups. Some students engaged Ph.D. programs and many of them still remember those participations and consider them as important aspects of their student life.

\section{FINAL COMMENTS}

PBL approaches are offered at U.Porto and at FEUP in a voluntary base for those more proactive students or in a curricular discipline for all students as is the case of "Project FEUP". This last one proved to be very important for
TABLE II.

AUTHOR'S INVOLVEMENT IN IJUP PROGRAM

\begin{tabular}{|l|l|l|}
\hline $\mathbf{N}^{\mathbf{0}}$ & Year & \multicolumn{1}{c|}{ Topic } \\
\hline 1 & 2004 & $\begin{array}{l}\text { Use of optical fibers for temperature and strain moni- } \\
\text { toring of a carbon fiber reinforced polymer along and } \\
\text { after the curing process (Team element) }\end{array}$ \\
\hline 2 & 2004 & $\begin{array}{l}\text { Development of a displacement transducer for civil } \\
\text { engineering applications (Leader) }\end{array}$ \\
\hline 3 & 2005 & $\begin{array}{l}\text { Displacement transducer for monitoring applications in } \\
\text { civil engineering (Team element) }\end{array}$ \\
\hline 4 & 2005 & Micro Displacement Remote Measurement (Leader) \\
\hline 5 & 2007 & $\begin{array}{l}\text { StrucTools - Experimental and virtual tools for teach- } \\
\text { ing structural mechanics (Team element) }\end{array}$ \\
\hline 6 & 2007 & $\begin{array}{l}\text { Development of a Hand Grip Dynamometer for Nutri- } \\
\text { tional Assessment (Team element) }\end{array}$ \\
\hline 7 & 2007 & $\begin{array}{l}\text { Virtual instrumentation for monitoring, digital record- } \\
\text { ing and assessing body composition (Leader) }\end{array}$ \\
\hline 8 & 2009 & $\begin{array}{l}\text { LipoTool: the Mechanical design of a new Calliper } \\
\text { (Team element) }\end{array}$ \\
\hline 9 & 2009 & $\begin{array}{l}\text { SeepTool - Small scale model for seepage studies } \\
\text { (Team element) }\end{array}$ \\
\hline 10 & 2009 & $\begin{array}{l}\text { Optical Fibre Pressure Sensor for Small Scale Studies } \\
\text { of Groundwater Flow (Team element) }\end{array}$ \\
\hline 11 & 2012 & $\begin{array}{l}\text { DINAM - Validation of a new prototype dynamometer } \\
\text { for evaluation of hand grip strength (running) (Leader) }\end{array}$ \\
\hline 12 & 2012 & $\begin{array}{l}\text { LabVIH - Virtual labs with haptic interaction (run- } \\
\text { ning) (Team element) }\end{array}$ \\
\hline
\end{tabular}

TABLE III

PROJECTS IN TABLE II AND TEAMS

\begin{tabular}{|l|c|c|c|c|c|c|c|c|c|c|c|c|}
\cline { 2 - 12 } \multicolumn{1}{l|}{} & $\mathbf{1}$ & $\mathbf{2}$ & $\mathbf{3}$ & $\mathbf{4}$ & $\mathbf{5}$ & $\mathbf{6}$ & $\mathbf{7}$ & $\mathbf{8}$ & $\mathbf{9}$ & $\mathbf{1}$ & $\mathbf{1}$ & $\mathbf{1}$ \\
\hline Mech. Eng. & RS & RS & RS & RS & R & RS & RS & RS & RS & RS & RS & RS \\
\hline Elect. Eng. & & S & & R & & & & & & & & \\
\hline Physic. Eng. & & & & R & & & & & & & & \\
\hline Inform. & & & & S & RS & & & & RS & & & S \\
\hline Civil Eng. & & RS & RS & & R & & & & RS & R & & \\
\hline Nutrition & & & & & & RS & RS & RS & & & RS & \\
\hline Multimed. & & & & S & S & & & S & & & S & \\
\hline Physics & RS & & & & & & & & RS & S & & \\
\hline Sports & & & & & & & RS & & & & RS & \\
\hline Architec- & & & & & S & & & & & & & \\
\hline Psychology & & & & & & & & & & & & RS \\
\hline CIAFEL & & & & & & & R & & & & & \\
\hline INESCP & R & & & & & & & & R & R & & \\
\hline INEGI & TR & & & & & & & & & & & \\
\hline CATIM & & T/S & T & & & T & T & & & & & \\
\hline Computer & & & & T & & & & & & & & \\
\hline Mech. & & T & T & & & T & T & T & & & T & \\
\hline Phys. & T & & & & & & & & & T & & \\
\hline
\end{tabular}

INESCP Instit. of Syst.\& Comput. Eng. Porto (Optoelectron. Group) INEGI Institute of Mechanical Engineering \& Industrial Management CATIM Support Center for the Metal-Mechanics Industry

CIAFEL Research Centre in Physical Activity, Health \& Leisure

helping new comers to FEUP, offering them better integration with mathematics and conceptual knowledge and a more realistic way of understanding how to work within FEUP and giving opportunity for learning many important aspects for their future life as students. On the other hand, the examples of EMPE project or iJUP Program increase drastically the students problem solving ability, how to apply learning, metacognitive skills, teamwork skills, communication and visual skills, the role of engineering in the society. For teachers it is grateful to perceive their student changes in attitude and in motivation. 
PAPER

\section{U.PORTO, ITS FACULTY OF ENGINEERING AND PBL APPROACHES}

In the present Integrated Master Degrees students have to realize a final project for their MSc theses in just 6 months. Currently their theses work is within R\&D teams. Other times, they have to make their work in Industry. In both cases they need definitely to prove their communication and teamwork skills and to understand professional practice. Once again the experience they get from the referred initiatives is instrumental for a successful conclusion of their study cycle.

\section{ACKNOWLEDGMENT}

U.Porto and FEUP have been supporting many of authors activities here reported. Other different activities within PEst-OE/EME/LA0022/2013, FCT, have also been supported with some R\&D resources. Thanks are due to all colleagues sharing some of these experiences.

\section{REFERENCES}

[1] https://sigarra.up.pt/feup/en/web_base.gera_pagina?p_pagina=247 026 (acceded June 2013)

[2] http://sigarra.up.pt/up/en/WEB_BASE.GERA_PAGINA?p_pagina $=122350$ (acceded June 2013)

[3] E.L. Boyer, The Boyer Commission on Educating Undergraduates in the Research University, Reinventing undergraduate education: A blueprint for America's research universities, Stony Brook, NY, 1998.

[4] E. Berkes, Higher Education "Sustainability Initative for Rio+20", http://escholarship.org/uc/item/7tr4c62k (acceded June 2013)

[5] E. de Graff and A. Kolmos, "Characteristics of Problem-Based Learning", Int. J. Engineering, Vol. 19, No. 5, pp. 657-662, 2003

[6] Rowan University, Center for Innovation \& Entrepreneurship http://www.rowan.edu/colleges/business/cie/aboutus.html (acceded June 2013)

[7] W. M. Clark, D. DiBiasio and A. G. Dixon, "An integrated, project-based, spiral curriculum for the first year of chemical engineering", FIE '98 Proceedings, 28th Annual Frontiers in Education, 1998.

[8] J. C. Marques, T. Restivo, P. Portela, R. Teixeira, "Cooperative Teaching Exploring a Multidisciplinary Engineering Problem", (2002), ASEE Annual Conference, Canadá, June 2002.

[9] W. F. Hosford and J. L. Duncan, "The Aluminium Beverage Can", Scientific American, Vol. 271, N. 3, pp. 34-39, 1994. http://dx.doi.org/10.1038/scientificamerican0994-48

[10] M. T. Restivo, J. C. Marques and T. Vieira, "Experimenta@FEUP" September 2007 [International Conference on Engineering Education Coimbra, Portugal]
[11] C. Rhodes \& A. Nevill, "Academic and social integration in higher education: a survey of satisfaction and dissatisfaction within a first-year education studies cohort at a new university", Journal of Further \& Higher Education; 28: 2, 179-193, 2004. http://dx.doi.org/10.1080/0309877042000206741

[12] L. Lund, D. Budny, "The Value Of A Service Learning Course For Freshman Engineers", , July 2006 [ICEE International Conference on Engineering Education].

[13] D. Budny, L. Lund, R. "Khanna, Designing Service Learning Projects for Freshman Engineering Students", International Journal of Engineering Pedagogy, Vol 3 (2013), pp. 31-38.

[14] M. Emilsson, "Training social competence in engineering education: necessary, possible or not even desirable? An explorative study from a surveying education programme", European Journal of Engineering Education, 33: 3, 259-269. http://dx.doi.org/10.1080/03043790802088376

[15] European Credit Transfer and Accumulation System (ECTS), http://ec.europa.eu/education/lifelong-learning-policy/ects_en.htm (acceded June 2013)

[16] P.C. Blumenfeld et al., "Motivating project-based learning: Sustaining the doing, supporting the learning, Educational Psychologist”, Educational Psychologist, Vol. 26 (3-4), p. 369-298, 1991, doi: http://dx.doi.org/10.1080/00461520.1991.9653139

[17] The Engineer of 2020, National Academy of Engineering, Washington, D.C., The National Academy Press.

[18] J. Ravitz, Project Based Learning as a Catalyst (AERA - New York), 2008.

[19] J. Gonçalves, M. T. Restivo and J. C. Marques, "IJUP - Young Research at University of Porto", 15th International Conference on Interactive Collaborative Learning (ICL), 2012 [Villach, Austria] http://dx.doi.org/10.1109/ICL.2012.6402023

[20] T. Andrade, "Project based learning activities in engineering education", 15th International Conference on Interactive Collaborative Learning (ICL), 2012 http://ieeexplore.ieee.org/ $\mathrm{xpl} /$ articleDetails.jsp?arnumber $=6402076$

[21] T. Andrade, L. Monteiro, R. Guerra, P. Carvalho, M. R. Quintas, C. M. Silva, T. Amaral, T. Restivo, M.F. Chouzal, J.M. Mendes, C. Sousa: "Development of an Handgrip Dynamometer for Nutricional Assessment", 2nd meeting of young researchers at UP, 2009 .

\section{AUTHORS}

M. T. Restivo is with IDMEC-Pólo FEUP and with the Mechanical Department at the Faculdade de Engenharia, Universidade do Porto, Rua Dr. Roberto Frias, 4200-465 Porto, Portugal (trestivo@fe.up.pt).

Submitted 14 October 2013. Published as re-submitted by the author 23 January 2014. 